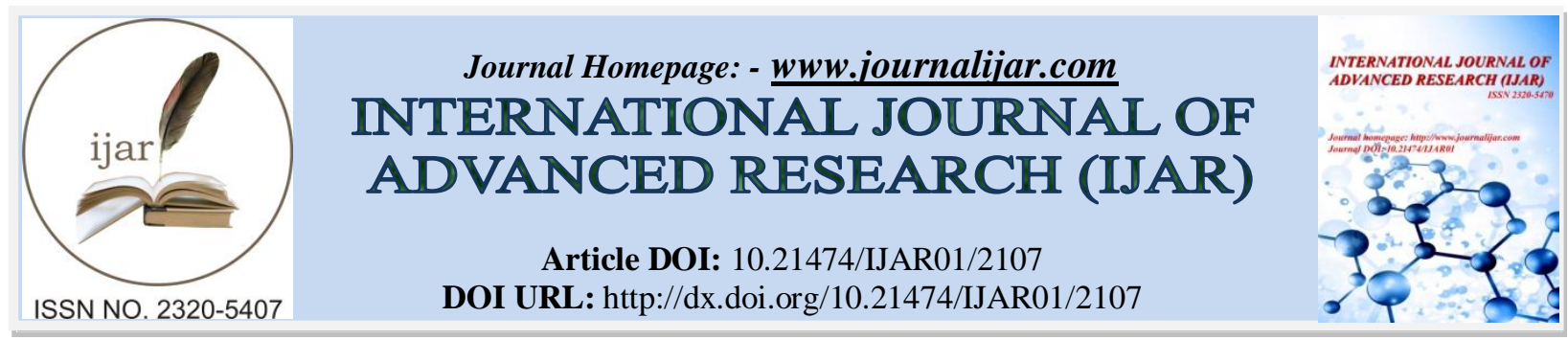

RESEARCH ARTICLE

\title{
AN ECONOMIC REVIEW OF FINANCIAL LIBERALIZATION REAL INTEREST RATES SAVINGS AND INVESTMENTS INTO EUROPEAN UNION.
}

"Dr. Stamatis Kontsas.

Adjunct Lecturer, Tecnological Education Institute of Western Macedonia, Department of Business Administration.

\section{Manuscript Info}

Manuscript History

Received: 25 September 2016

Final Accepted: 27 October 2016

Published: November 2016

Key words:-

Financial liberalization, interest rates, savings, investments, capital accumulation, regulation

Jel codes: G24,G30 ,F62,F63, F45

\section{Abstract}

The Euro area households' gross investment rate increased significantly, peaking at $11.3 \%$ in 2007 . Investment growth varied between countries and is partly explained by differences in the initial levels of living conditions. For example, investment growth in 2005-07 was higher in countries which had a higher overcrowding rate, i.e. in countries with a higher share of households that do not have at their disposal a given minimum number of rooms (e.g. Estonia, Slovakia and Latvia). However, these developments were unsustainable. From 2008 there was a dramatic change and household investment started to fall sharply. Although this happened in most euro areacountries, it was particularly evident in those countries that had previously seen veryrapid growth in investment, such as Latvia, Estonia, Cyprus, Ireland and Greece.

In recent years household investment has continued to decline across the euro area as a whole. Investment fell by $3.7 \%$ at constant prices in 2013, and ended up $18 \%$ lower than in 2000. The picture has been varied across countries, however, and investment has increased in recent years in Germany, Estonia, Latvia and Slovakia.

Interest rate liberalization may not produce the expected benefits if the timing, pace, and sequencing are off. These should be determined by the degree of macroeconomic stability, conditions in the bankingand state enterprise sectors, and the central bank's capabilities.

Copy Right, IJAR, 2016,. All rights reserved.

\section{Introduction:-}

The financial system affects capital accumulation either by increasing saving rate (level effect) or by improving the allocation of savings among potential investors (reallocation effect). The availability of funds may also affect economic growth by financing technological innovation.

Financial liberalization reforms involve usually several key phases that are implemented in several years. These reforms cover interest rates, reserves requirements, credit allocation, bank ownership, pro-competition measures, security markets, prudential regulation, and openness of capital account.

At the start of the 2000s, household investment increased by $4-5 \%$ in nominal terms in the euro area, and by $1-2 \%$ in real terms, i.e. at about the same rate as growth in disposable household income. The exception was 2001 , when the 
bursting of the dot-com bubble saw a halt to growth in household investment, probably because of increased uncertainty.

In recent years, many developing and transition countries have allowedmarket forces to play a greater role intheir economies. In the financial sector,this means liberalizing interest rates sothat they are allowed to be set by the market and developing financial markets sothat credit can be allocated more efficiently.(Bandiera et al.,2000) Although each country must design itsown blueprint for financial reform, some general principles seem to be universallyapplicable, at least in countries where policymakershave some control over the liberalizationprocess. First, policymakers needto decide when to start liberalizing interestrates and how fast to move.

In making this decision, it is important to consider how faradvanced the country is in reforming thestate enterprise sector and in establishing a"credit culture"-that is, the extent towhich banks have become accustomed tousing market principles in assessing creditrisks. Second, they need to determine theappropriate sequencing of liberalization - the order in which interest rates on differentfinancial instruments can be freed withoutthreatening the health of the country'sbanking system.

(Kim, Singal, 2000).

Third, the central bank needs to develop a strategy for conductingmonetary policy within the framework of a liberalized financial system. To allowmarket forces to determine the allocation of financial resources, countries need to develop an efficient money market. And, policy makers need to be prepared for thefinancial innovations that will inevitablyfollow liberalization.(Bekaert, Harvey, 2000)

\section{An Economic Approach on Development Framework Aspects:-}

To date the empirical relationship between financial system development and saving, investment and economic growth has been difficult to test. Two streams of research maybe distinguished. The first investigates more generally the relationships between financial development indicators and economic performance (King, Levine ,1993). The second focuses more specifically on the impact of financial liberalization on economic performance (Kim,Singal,2000).

King and Levine (1993), examine whether higher level of financial development are positively associated with economic development using data over 80 countries from 1969through 1989. Four indicators have been constructed in order to measure financialdevelopment. First, the ratio of liquid liabilities to GDP. Second, the importance ofdeposit banks relative to the central bank in allocating credit. Third, the share of credit issued to non-financial institutions (in total credit and in GDP). Using this array ofindicators provide much better picture of financial depth than using a single indicator.

Using cross-country regressions and after controlling for a set of country and policy characteristics, they find that higher levels of financial development are positively associated with faster rates of economic growth and physical capital accumulation. They also point out that financial development is a good predictor for long-run economicgrowth over the next 10 to 30 years. These finding confirm that finance does not onlyfollow economic activity and that the strong correlation between the level of financialdepth and economic growth does not simply reflect a positive association between contemporaneous shocks to both financial and economic development.

\section{Macroeconomic Empirical Findings:-}

Since the beginning of the crisis, euro area households have had to adapt their decisions to an adverse macroeconomic backdrop, characterized by a high degree of uncertainty, accompanied by a marked decrease in consumer confidence.(Kim, Singal, , 2000).

Following the outbreak of the financial crisis in 2008, the indicator of macroeconomic uncertainty in the euro area, which is a summary measure of various measures of economic, financial and economic policy uncertainty, picked up sharply, reflecting similar developments across all its components.

(https://www.ecb.europa.eu/pub/pdf/scpops/ecbop167.en.pdf, 15/10/2016)

After falling back somewhat in the course of 2009 and 2010, all indices then rose again in the second half of 2011, during the euro area sovereign debt crisis. 
Graph 1:- Euro area household savings rate, consumer confidence and macro-economic uncertainty Euro area household savings rate, consumer confidence and macro-economic uncertainty

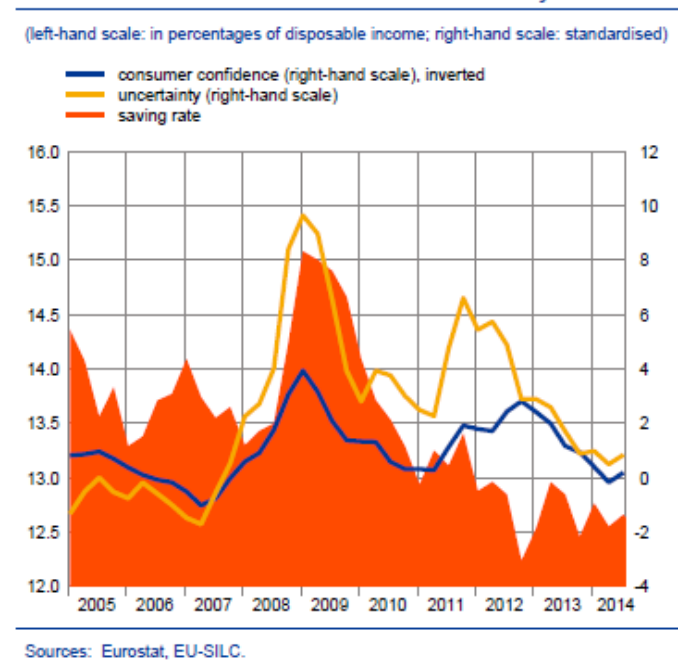

Against this background, the household savings rate, as a percentage of their disposable income, temporarily increased in most of the countries during the early stages of the crisis, as households appeared to increase their precautionary savings.(https://www.ecb.europa.eu/pub/pdf/scpops/ecbop167.en.pdf, 15/10/2016)

Graph 2 and 3:- Developments in household's savings rate a cross euro area countries. Developments in households' savings rate across euro area countries

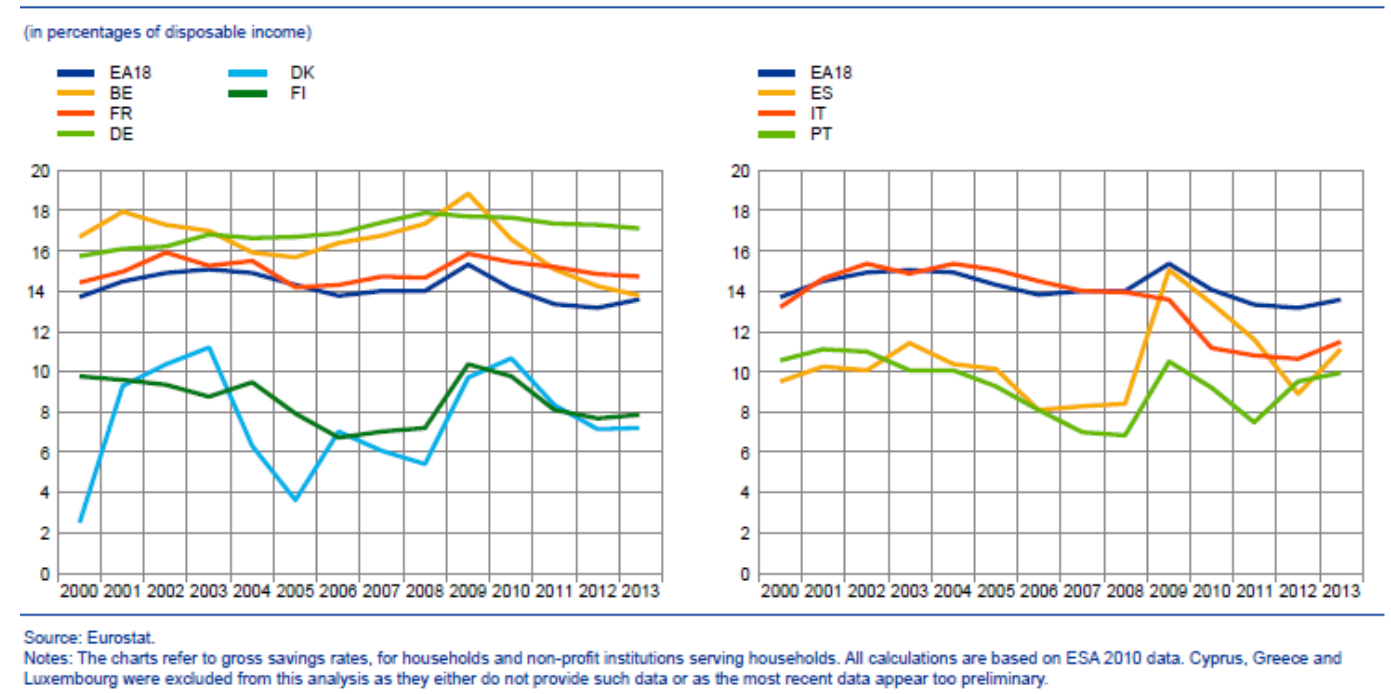

In some countries subject to a high degree of macro-financial uncertainty, like Ireland, Portugal and Spain, the pickup in the savings rate was particularly pronounced and, in spite of the downward correction in the 2010-2011 period, stayed in 2013 at a higher level than observed before the crisis. By contrast, in Italy, the savings rate has been on a downward path since 2006 and was below the euro area average by the end of 2013. In other countries, such as Germany and France, savings rates have remained relatively stable and generally above those registered by the stressed countries. 
Graph 4:- Gross disposable income and breakdown by end-use. Gross disposable income and breakdown by end-use

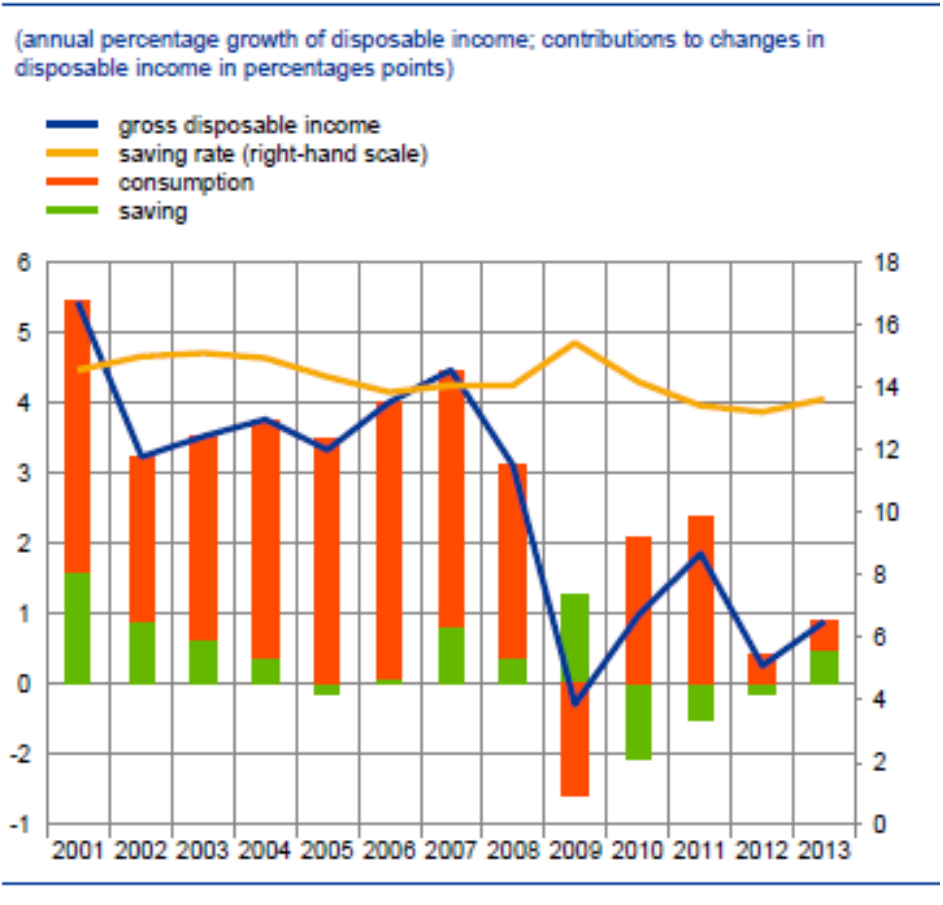

Sources: Eurostat and Eurosystem staff calculations calculations.

The fluctuations in the household savings rate during the crisis suggest the presence of factors with countervailing influences on this variable, relating both to developments in households' disposable income and the sensitivity in consumption to these changes.In general, households' savings behavior has been largely influenced by changes in disposable income.

In the period before the crisis, disposable income and the savings rate of the euro area were broadly stable. In 2009, however, the developments in the savings rate and disposable income diverged. As a consequence of the impact of the financial crisis, the nominal income and private consumption of the euro area households decreased sharply.(https://www.ecb.europa.eu/pub/pdf/scpops/ecbop167.en.pdf, 15/10/2016)

The savings rate picked up, mostly due to precautionary reasons. Since 2010, the importance of precautionary reasons might have declined somewhat and household income began to increase, in spite of continuing, significant job destruction and the onset of a severe fiscal consolidation process in some countries.

This increase was accompanied by a fall in savings and by increases in household nominal consumption. The fact that the savings rate has remained lower than its pre-crisis level appears consistent with some consumptionsmoothing behavior by euro area households.

To the extent that reductions in income, when compared with the pre-crisis level, were perceived as temporary, this appears to have resulted in reductions in the savings rate.

(https://www.ecb.europa.eu/pub/pdf/scpops/ecbop167.en.pdf, 15/10/2016)

It is also possible that the propensity to save decreases during phases of very sharp declines in income as households may encounter short-term obstacles to adjusting their consumption by the same proportion. These obstacles may stem from the existence of habits, minimum consumption thresholds for certain goods and contractual relationships for the supply of certain services, which, overall, seem to reduce households' capacity to respond in the short-term to negative shocks in their income.

Beyond this, there is also evidence that other factors, particularly the dynamics of housing debt and deleveraging, may have accentuated the impact of the traditional determinants of consumption in some countries. 
(https://www.ecb.europa.eu/pub/pdf/scpops/ecbop167.en.pdf, 15/10/2016)

As for the savings rate, there have also been different patterns in consumption, income and savings across the euro area member states.

In the period before the crisis, disposable income increased inall euro area member states, with most countries registering a rise in the savings rate.

Since 2009, disposable income has decelerated significantly in some stressed countries such as Italy and Portugal. However, although in Italy the decline in consumption was not enough to offset the decrease in income, resulting in a further decline in the savings rate until 2013, the savings rates in Spain and Portugal in 2013 were above their respective levels in 2008.

By contrast, in Germany and France, gross disposable income continued to grow over the more recent period, allowing consumption to increase while maintaining the savings rate at a relatively stable level.

(https://www.ecb.europa.eu/pub/pdf/scpops/ecbop167.en.pdf, 15/10/2016)

As for savings, the distribution of wealth is very unequal, with wealth being highly concentrated at the top end of the wealth distribution.

In the euro area, the top decile holds more than $50 \%$ of net wealth, while $50 \%$ of the households below or just at the median level hold only $12 \%$ of net wealth.

As regards the composition of assets, real assets represent the predominant asset category in all euro area countries (accounting on average for $85 \%$ of total assets), but differences in the composition of aggregate wealth are considerable.

While the value of the main residence tends to be the major asset for homeowners and represents a significant part of total assets in all countries, homeownership varies strongly between countries, ranging from $44 \%$ in Germany to $90 \%$ in Slovakia. All other asset categories account for substantially smaller shares of gross wealth.

(https://www.ecb.europa.eu/pub/pdf/scpops/ecbop167.en.pdf, 15/10/2016)

Graph 5 and Graph 6:- Gross disposable income and savings rate by country

(a) $1999-2007$
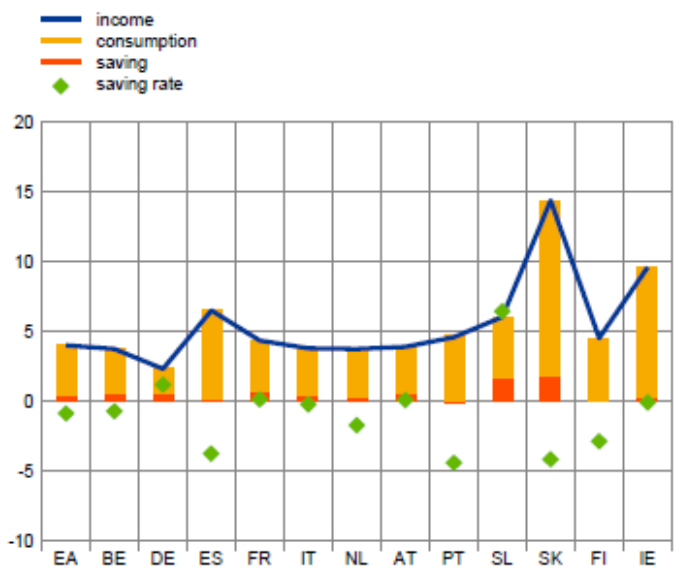

(b) $2008-2013$
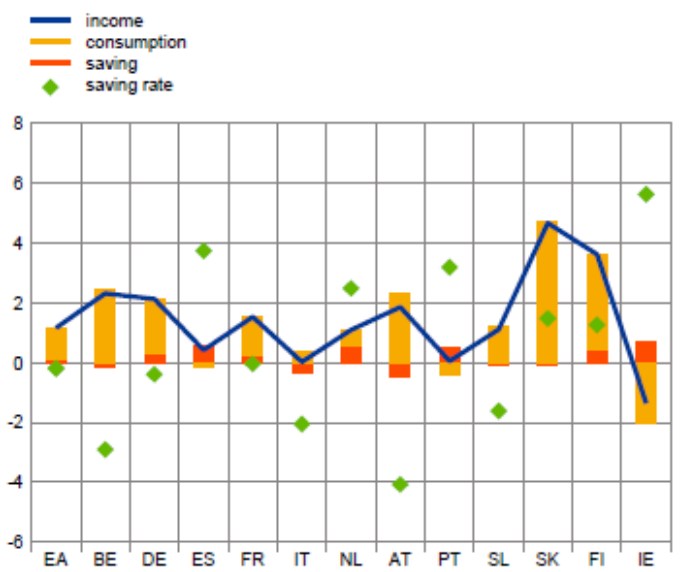

Source: Eurostat.

Most contemporary consumption-savings theories can trace back their foundation to the life-cycle hypothesis, which, in its simplest form, posits that consumers try to maximize their lifetime expected utility subject to an intertemporal budget constraint. The optimalsolution is that consumers facing a rising age-income profile will try to smooth their consumption through time by borrowing when young and repaying their debt later in their life-cycle. Therefore a household is expected to borrow at a young age, accumulate resources during middle age and again after retirement. Hence age, demographic structure and real disposable income, i.e. earnings plus investment income and 
government transfers, are generally considered as important variables in shaping households' savings behavior. Public insurance schemes also influence households' savings.(Laeven, Valencia, 2008)

In particular, the availability of generous government-provided retirement income programs should substantially reduce the incentive for younger households to save. Indeed, in the presence of a "pay-as-you-go" pension system households could consider their retirement benefits as a substitute for their working-age savings and as a result could tend to reduce their pre-retirement savings.

It must be noted though that such a depressing effect on private savings stems from a very restricted form of the lifecycle hypothesis, in which intergenerational private transfer schemes are not taken into account. Simple versions of the life-cycle model assume that individuals are far-sighted and that future variables such as income, interest rates, family composition, rate of survival and date of death are known with certainty.

This so-called certainty equivalence assumption was relaxed towards the end of the 80 's and the effect of uncertainty, in particular on income and on households' savings behavior has been investigated. If income streams are stochastic, then risk-averse households will tend to show a precautionary behavior in their consumption patterns by accumulating a buffer stock of wealth to insure themselves against possible negative shocks.(Prean, Stix,2011).

Other key assumptions and predictions of the basic version of the life-cycle model have not been supported by empirical evidence and have thus prompted a search for new mechanisms and variables that can be relevant in accounting for households' savings behavior.

In particular, although the basic model assumes perfect capital markets, so that households face no impediments in borrowing against their future income to finance current consumption, households in practice do face limits on their ability to borrow against their future resources. (Stix,2013)

Young low-income households, in particular, may face liquidity constraints that prevents them from consuming as much as they would like to, causing their consumption path to increase over the life-cycle.(Stix,2013)

Once the assumption of perfect capital markets is relaxed, the structure of credit institutionsbecomes relevant. The majority of household's credit is linked to mortgages, hence consumers in countries with relatively limited access to credit must accumulate a larger down-payment, and accordingly save a higher fraction of their income, before they can purchase a home. Conversely, the higher the ratio of credit to disposable income in a country, the lower its households' savings rate is expected to be. (Prean, Stix,2011).

A growing literature has focused on the effect of a relaxation of borrowing constraints on consumption growth, finding this effect to be quantitatively sizable both in explaining increases in consumption - and thus ceteris paribus a decrease in savings - in periods of rapid credit growth, as well as prolonged reductions in consumption following a credit crunch, in particular, finds that the effects of changes in housing wealth effects on consumption are much stronger in periods of rapid credit growth and can even be greater than the effects related to changes in liquid wealth.(Laeven, Valencia, 2008)

Given the sizeable increases in household sector debt observed across many countries prior to the crisis and the need for balance sheet repair, recent studies show that household debt reduction tends to be accompanied by increases in savings, partly linked to factors already considered above.

A tightening in credit conditions, for instance, is typically accompanied by a reduction in debt and an increase in savings as households cannot borrow as easily as before to offset negative income shocks. Similarly, house price declines are associated with lower debt, as they reduce the availability of home-equity-based borrowing, leading to lower consumption.

Beyond this, households may target a given level of leverage and reduce their consumption to restore assets in response to a negative wealth shock based on household-level data for the United States).

However, given that household deleveraging has so far remained limited, the available studies generally conclude that household balance sheet adjustment has not been an important factor behind the sluggish economic recovery. Macro-economic risks related to future household deleveraging nevertheless remain. According to a recent analysis 
by the European Commission, households in at least seven euro area countries exhibit a high likelihood of a need for further significant deleveraging. Finally, developments in fiscal policy could also influence households savings behavior, in line with the insight provided by the Ricardian equivalence theory: after an increase in public debt, households would tend to save more in expectation ofhigher taxes by the government in the future.(Beckmann et.al.,2013).

Hence, over the long run, countries characterized by relatively higher levels of public debt should also have higher accumulated savings by households.

In general, households finance their investments by using their current incomes, which is considered to be the most important determinant of household investment, or by borrowing from the credit market or using their accumulated savings.(Beckmann, Stix,2015) Households invest mainly in housing. Therefore home-ownership and developments in residential real estate markets could be expected to influence household investment behavior. (Brown, Stix, 2015) As the need for housing also depends on the demographicstructure of the population, demographic trends should influence investment as well.

Since investment decisions depend on confidence, it could be assumed that the more certain households are about the future, the more investments they are willing to make.(Kim, Singal, 2000).

\section{Concluding Remarks:-}

In order to understand the motives underlying these savings decisions and to have some clue as to the reasons for the deviations from the standard life-cycle model, this subsection takes advantage of the information included in the first wave of the HFCS. The HFCS, which was conducted in 15 euro area countries, in 2010/11 in most cases, includes data on the most important self-reported motives for savings.

These data are collected with a multiple choice question, which means each household can identify several important reasons for savings. According to these data, in the euro area as a whole, the most important motive for savings is the provision for unexpected events, which captures the precautionary savings motive.

The next most important motives are old age provision, majorpurchases other than own home (which includes, for instance, other residences, vehicles and furniture), travel/holidays and the education or support of children or grandchildren.

The relative importance of the different motives is rather similar across countries. The data on savings motives are useful to better understand the savings behavior of different households. With that aim, present the percentage of households choosing each of the most important motives, by age class of the reference person, by income percentile and by net-wealth percentile, respectively.

In the case of age, the percentage of households choosing savings for old-age provision as an important motive increases until the retirement age and declines afterwards. This kind of hump-shaped profile is not found in the other motives for savings, which might explain the deviations in the savings behavior from the predictions of the standard life-cycle model. For the provision for unexpected events, which is the most important motive across all age classes, the percentage of households choosing this motive does not change much with age.

This behavior might reflect the existence of different reasons justifying precautionary savings in different age groups, for instance in the oldest, the health risk and in the youngest, the accumulation of a precautionary buffer of wealth at the beginning of working life. Savings for education/support of children and grandchildren are slightly more important for the 35-45 age class, in line with the predominance of households with children in this age group, but does not present also a significant age profile.

By contrast, the importance of savings for bequests keeps an upward trend with age and thus might contribute to justify the persistence of high savings rates in old-ages. On the contrary, savings for major purchases and for travel/holidays decline with age and in a more pronounced way in very old ages. Savings for own-home purchases also decline with age and are particularly important for the youngest households. 
During the years leading up to the financial crisis, growth in household investment grew at a rate that was notably higher than disposable household income growth. Households had to borrow the additional funds needed for investment, and this led household debt to increase significantly.

\section{References:-}

1. Bandiera et al. (2000), Does Financial reform raise or reduce saving? The Review of

2. Economics and Statistics, 82(2): 239-263.

3. Beckmann, E., Hake, M., Urvova, J. (2013).Determinants of Households' Savings in Central, Eastern and Southeastern Europe.Focus on European Economic Integration Q3/13, 8-29.

4. Beckmann, E. and Stix, H., (2015). Foreign Currency Borrowing and Knowledge About Exchange Rate Risk, Journal of Economic Behavior and Organization, 112, 1-16.

5. Bekaert, G., Harvey, C. (2000) Foreign speculators and emerging equity markets. Journal of Finance 55, 565613

6. Brown, M. and Stix, H., (2015).The Euroization of Bank Deposits in Eastern Europe.Economic Policy.

7. Kim, E.H., Singal, V., (2000). Stock market openings: experience of emerging economies. Journal of Business 73, 25-66.

8. King, R.G., Levine, R., (1993). Finance and growth: Schumpeter might be right. Quarterly Journal of Economics, 108(3), 717-37.

9. Laeven, L. and Valencia, F., (2008).Systemic Banking Crisis: A New Database. IMF Working Paper 224.

10. Prean, N. and Stix, H., (2011). The effect of raising deposit insurance coverage in times of financial crisis Evidence from Croatian Microdata, Economic Systems, 35, 496-511.

11. Savings and investment behavior in the euro area, available at:

12. https://www.ecb.europa.eu/pub/pdf/scpops/ecbop167.en.pdf, assessed at: 15/10/2016

13. Stix, H.,( 2013). Why do people save in cash? Distrust, memories of banking crises, weak institutions and dollarization. Journal of Banking and Finance, 37(11), 4087-4106 